\title{
VOX REDACTORIS
}

DOI 10.15826/qr.2019.2.381

\section{RUSSIA: THE SEARCH FOR MEANING IN CULTURE AND HISTORY}

Quaestio Rossica (No 2, 2019) has a distinctive focus on the history of culture and art. This manifests the desire of participating researchers and the editorial board to hear the echoes of history - the sound of the 'division bell' and the disturbing melodies of modernity, transformed by the creative consciousness into material monuments and emotional experiences. This issue unites two opposing poles of sociocultural space.

The theme of monstrosity embodies either the anticipation or the disintegration of harmonious Divine Creation. One of the statements of Igor Smirnov, a prominent theoretician of history, might serve as a heraldic motto for this theme: "Art is fearless in the face of degeneration, depriving it of supreme power, making it manageable, and putting it under control" [Смирнов, с. 11]. Thus, this issue of QR presents examples of "curbing" the advance of chaos through aestheticising monstrosity or demonism and overcoming the fear of entropy.

The opposite pole in this confrontation is the phenomenon of sociocultural communication, reconciling people both in their successes and in their misfortunes. The ineradicable desire to rejoice, to enrich one's own emotional and conceptual reality through the artifacts and institutions of other cultures is what incites the development of civilization. This theme has been repeatedly raised in the pages of $Q R$ in various ways: biographical [Zhuk; Христофоров], historical and scientific [Куденис], sociocultural [Binney; Приказчикова; Вачева], and the history of everyday life [Кароли].

An article about Johannes Baar, a prominent German professor of philology, looks at the unique ability of human beings to reconsider their and others' experiences, to learn life lessons, and to organise their earthly existence in accordance with an acquired system of values. The Second World War was Professor Baar's true university. The courage of this academic researcher consisted not only in the fact that he retained his ability to empathize and open his heart to pain amidst a military catastrophe, as his wartime letters show; he also had the inner strength to move from instigated hatred to recognition of the cultural perfection of the Russian language and literature and to devote his further life to studying them. The materials on Professor Baar's academic life, especially his wartime letters, are published in the Scientia et vitae section by professors Boris Kovalenko, Valery Mokiyenko (St. Petersburg State University), and Christine Mielsch (Hamburg Association of Teachers of Russian Language and Literature), a German specialist in Russian studies. 
The Problema voluminis section, entitled "Demons and Monsters in Russian Culture", continues the publication of material on artistic expressions of bodily anomalies (see: [Quaestio Rossica. 2019. Vol. 7. № 1. C. 140-240]). Art often reveals the catastrophic dimension of world order through imagery of bodily imperfection and ugliness, manifested in magical artifacts or mystical transformations. In this issue of $Q R$, the theme of demonic and monstrous imagery in Russian culture opens with an article about the works of Mikhail Vrubel by the art critics Evgeny Alekseev and Andrey Merezhnikov (Ural Federal University, Yekaterinburg). The authors explore new aspects of the demonic theme, revealing the genetically diverse elements in the artist's imagery. Presented in a series of paintings by Mikhail Vrubel, the image of the demon is put alongside the "painful phantasms" of late $19^{\text {th }}$-century European art.

The article by Natalia Prashcheruk (Ural Federal University, Yekaterinburg) about the writings of Ivan Bunin continues examining the theme of the catastrophic state of the Russian world at the turn of the century, revealing Bunin's artistic method of reflecting on his contemporaries' assessment of his work. On the basis of qualitative semiotic analysis, Dr Prashcheruk exposes the dramatic experiences of the writer and his insight into the essence of the historical process of the time - the destruction of cultural foundations, gambling with death, and the appearance of moral monsters in people's souls.

$Q R$ continues to publish materials from the colloquium "Deviant bodies in Russian culture" (University of Geneva, 23-24 February 2018), turning this time to "pathology", i. e. everything that has appeared and appears as physical anomalies against the background of nature and/or culture ${ }^{1}$. This pathologisation is demonstrated in an article by Annick Morard (University of Geneva) on the perception of hypertrichosis (excessive hairiness), which at the end of the $19^{\text {th }}$ century had become a differentiating sign separating "real humans" from the "other". This process, which includes not only anthropology but also literature, is related to the creation of Utopias and anti-Utopias via the use of this particular differential characteristic. The author rightly recalls the practice of showing such people to satisfy the curiosity of the crowd in spectacles, thus warning society against possible manifestations of inhumanity.

The article of Yaroslava Ismukova (Institute of Russian Literature, RAS, St Petersburg) analyses "conceptual monsters" in the works of Dmitry Prigov. Juxtaposing examples of the writer's behaviour during his public speeches against his texts, the author forms a conceptual space of creativity, where monstrosity as a quality serves as the main basis for the design of his poetic world.

The brilliant album of graphic work of the famous Ural artist Vitaly Volovich, entitled Women and Monsters, is at the center of Lev Zaks' study (University for the Humanities, Yekaterinburg). The researcher

${ }^{1}$ The editorial board wishes to express our gratitude to the organizers of the colloquium: Professor Konstantin Bogdanov of the NRI HSE (St Petersburg) and Phd Annick Morard, University of Geneva, for their valuable contribution to the formation of this section of $Q R$. 
reveals a variety of artistic expressions of monstrosity, including vivid manifestations of eroticism and sexuality with a wide variety of connotations. The feelings expressed in the artist's graphic art fluctuate from fear to the comical and from horror to love, delivering genuine delight to art connoisseurs.

The second major theme of the issue ("Russians and Foreigners in a Cross-Cultural Space: Ideas and People") concerns the virtuous function of culture that aims to overcome people's separation, remove historical, linguistic, and social restrictions and expand opportunities to cooperate. The ability of the Russian world to engage in a wide range of contacts with the "alien" and its confidence in eventual success of interactions with the "Other" in the past and present are not only the basis for the selection of articles in this issue, but also form a unifying idea for members of the editorial board, as has been repeatedly noted in our editorials [Redin, Soboleva]. This important theme continues from one issue to the next and is constantly present in our sphere of interests.

This section of the issue is structured chronologically: thus, it opens with articles devoted to the history of language contacts, in particular the interaction between Old Church Slavonic and Latin. The article of Ekaterina Kislova (Moscow State University), based on archival sources, describes the pedagogical activity of Archbishop Feodosy (Yanovsky) and his work on the creation of new nationally oriented motivations for studying Old Church Slavonic in the first quarter of the $18^{\text {th }}$ century. The researcher offers new information that clarifies the process of teacher training and the foundation of a new way for teaching Old Church Slavonic through grammar. Maya Petrova (Institute of World History of RAS, Moscow) discusses the movement of Russia towards the European education system in terms of the dissemination of Latin, the scientific language of the Middle Ages: this helped unite the intellectuals of Europe and learned Russian circles. Priscian's grammar $\left(5^{\text {th }}-6^{\text {th }}\right.$ centuries AD) and a European (German) edited translation were the source for the $16^{\text {th }}$-century grammatical composition of D. Gerasimov (Donatus), a herald of the future aspirations of the enlightened clergy to elaborate a systematic morphology of Old Church Slavonic.

The collaboration between Alexander Stroyev (New Sorbonne University, Paris-3) and Denis Kondakov (Polotsk State University) is based on original police reports from the first half of the $18^{\text {th }}$ century. The article retells the events concerning peculiarities in the adaptation of two diplomats - the Russian prince and poet Antioch Cantemir and Danish Count von Bernstorff - to high Parisian society. They never managed to become an integral part of the French elite, but the comparison of their behaviour reveals fundamentally different methods of conquering the sympathy of others in the course of their diplomatic activity.

The appeal of Catherine II and her entourage to European ideas of the Enlightenment is at the center of the study by Ludmila Artamonova (Samara State Institute of Culture). The ideology at the basis of the Russian aristocracy's attitudes and views was matched by their behavioural practices, convincingly demonstrating the movement towards the "appropriation" of 
European rules of life (both external and internal). The emotional and sensual aspect of sentimental and pre-romantic representations was embodied in book illustrations of the late $18^{\text {th }}$ century. According to the conclusions of Elena Borshch (Ural State University of Architecture and Art, Yekaterinburg), these illustrations, despite their distinctly European origins, underwent a significant redesign in Russian editions.

Human relationships have also become an important sphere of interaction within various cultural traditions in different epochs. Historian $M a-$ rie-Pierre Rey (Paris I Panthéon Sorbonne University, Paris; Ural Federal University, Yekaterinburg), basing her research on the memoirs of French writer and diplomat Chateaubriand, describes the nature of his relationship with the Russian Emperor Alexander I. The researcher's careful eye is attracted by the philosopher's evaluation of the emperor's personal drama: quite inconsistently, his personality combined both political ambitions and human empathy.

Trade and commerce are certainly among the most remarkable examples of cross-cultural interactions in history. One highly ambitious attempt to forge Soviet-Canadian commercial relations in the midst of a conflict zone is presented by Robrecht Declercq (University of Ghent). The author uses documents from the Hudson's Bay Company adventure in Kamchatka and Eastern Siberia (1919-1925) about a commercially unsuccessful expedition, which nonetheless enriched Russian ethnography, geography, and history with unique information. The rather successful interaction of the expedition's participants with the local population and state authorities unfortunately proved to be insufficient for commercial success due to the incredible distances and harsh climate of Russia's eastern territories.

The Conceptus et conceptio section presents a joint article by Igor Isaev, Arkadiy Kornev, and Sergei Lipen (Moscow State Law University) on the formation of the theory of political power technologies in modern philosophy. The authors see a connection between the theory and modern tendencies of political power structures and create a system of warnings that allows one to see manipulative strategies in politics and lawmaking.

The Disputatio section presents articles saturated with new materials and ideas. Denis Lyapin (Yelets State University) discusses the social organisation of the rural population and its role in public, governmental, and private spheres in the $17^{\text {th }}$ century. Using the example of the Russian south, this study of the social organisation of the rural population, which at that time constituted the vast majority of the population, provides precise characteristics about life in a border territory.

The two following articles refer to the fates of people connected by numerous threads with the surrounding world - its prejudices and class constraints, its limitations and stupidity, on the one hand, and its human decency and noble aspirations on the other. Vladimir Shkerin's article (Institute of History and Archaeology of the Urals Branch of RAS, Yekaterinburg) reminds us of the reasons for the strict conditions of Ukrainian poet 
Taras Shevchenko's political exile after he wrote invectives regarding the bodily weaknesses of the Russian empress. Social clashes sometimes have an inadequate, unreasonably personal form of expression in the behaviour of the exiled poet, who was unable to believe in the goodwill of the local authorities when confronted with harsh administrative restrictions. An interesting problem is raised in the article of Alexander Kamenskii (Higher School of Economics, Moscow), which stems from the researcher's desire to understand an extreme expression of human self-denial - suicide as a response to the conditions of a despotic state. This is developed by Kamenskii as the concept of "state fear". As he shows, this feeling was amplified during periods of total control and the depersonalisation of power, when a bureaucratised, indifferent attitude to a person's fate that failed to take into account the circumstances and causes of their actions predominated.

The everyday conditions of children's upbringing, including the development of fashion, became an object of attention for the clothing industry in the $19^{\text {th }}$ century. The new understanding of childhood as a period no less important than adulthood, albeit with its own peculiarities, led, as is shown by Natalia Pushkareva (Institute of Ethnology and Anthropology of RAS, Moscow) and Natalia Mitsyuk (Smolensk State Medical University), to the appearance of true infant fashion. The main aim of such fashion was releasing the child from the restrictions of swaddling and making clothes more comfortable and functional, thereby supplying the public demand for a new type of younger generation. The article is accompanied by illustrations (sketches and photos of clothes), which are the documentary basis for the authors' conclusions.

The Controversiae et recensiones section presents two reviews that raise questions about the political history of Muscovite Rus' in the $15^{\text {th }}$ and $16^{\text {th }}$ centuries. The review of Bulat Rakhimzianov (Institute of History of RAS, Kazan) presents serious objections to A. V. Aksanov's claims of having provided a comprehensive hermeneutic interpretation of the history of relations between the Kazan Khanate and Muscovite Rus. The review analyses in detail the logic and argumentation behind the research, concluding that the positivist approach (rather than a hermeneutic one) overwhelmingly dominates the monograph. The controversial and argumentative character of the review make it especially valuable to the academic reader.

The review of Ulyana Golovacheva (Ural Federal University, Yekaterinburg) considers a monograph by M. M. Krom dedicated to the birth of the Muscovite state. It seems that the popular character of the monograph complicates not only the author's task, but also the position of the reviewer, who aspires to understand the intentions of the Petersburg historian. The monograph, the reviewer notes, tries to follow the historic path of Russia towards the idea of the state, connecting well-known facts with newly discovered information.

Larisa Soboleva

Ural Federal University,

Yekaterinburg, Russia

(C) Dergacheva A., translation, 2019 
Представленный номер журнала имеет явный крен в историю культуры и искусства. Это обусловлено желанием услышать эхо истории, звук колокола и тревожные мелодии современности, преображенные творческим сознанием в материальные памятники и душевные переживания. В выпуске объединены два полюса социокультурного пространства. В теме монструозности образно воплощаются предвестие или результат распада гармонического Божественного творения. Как нельзя кстати здесь одно из высказываний Игоря Смирнова: «Искусство бесстрашно перед лицом вырождения, лишает его единодержавной власти, делает его управляемым, ставит под контроль» [Смирнов, c. 11]. Примеры подобного «обуздывания» процесса наступления хаоса через эстетизацию монструозности и демонизма и преодоление страха энтропии представлены в данном выпуске журнала.

Противоположным полюсом в этом противостоянии является феномен социокультурной коммуникации, сближающей людей как при успешном жизненном сценарии, так и в негативных перипетиях. Неистребимое желание приобщиться, обогатить эмоциональный и понятийный мир через артефакты и институты иной культуры дает импульс развитию цивилизации. Эта тема неоднократно поднималась на страницах журнала в разных аспектах: биографических [Zhuk; Христофоров], историко-научных [Куденис], социокультурных [Binney; Приказчикова; Вачева], бытовых [Кароли].

Уникальной способности человека пересмотреть свой и чужой опыт, извлечь жизненные уроки и организовать земное пребывание в соответствии с обретенной системой ценностей посвящен материал о немецком профессоре филологии Йоханнесе Бааре. Его настоящим университетом стала Вторая мировая война. Мужество этого исследователя состояло не только в том, что он сохранил, как о том повествуют его военные письма, способность к сочувствию и ощущение душевной боли в военной катастрофе, у него хватило внутренней силы перейти от внушаемой ненависти к признанию культурного совершенства русского языка и литературы и посвятить им дальнейшую жизнь. Об этом с обширным цитированием военных писем Баара пишут в рубрике Scientia et vitae петербургские профессора Борис Коваленко и Валерий Мокиенко (Санкт-Петербургский государственный университет), а также немецкий специалист по русистике Кристина Мильи (Гамбургская ассоциация преподавателей русского языка и литературы).

В рубрике Problema voluminis «Демоны и монстры в русской культуре» продолжается публикация материалов предыдущего выпуска о телесных аномалиях в художественном воплощении (см.: [Quaestio Rossica. T. 7. 2019. № 1. С. 140-240]). Катастрофический аспект мироустройства искусство открывает человеку в образах телесного несовершенства и уродства, выходя в артефактах к магическому и мистическому преображению. Исследования в области демонических и монструозных образов русской культуры открываются в журнале статьей искусствоведов Уральского федерального университета Евгения Алексеева и Андрея Мережникова о творчестве Михаила Врубеля. 
Авторы исследуют новые аспекты в раскрытии демонической темы, открывая ее генетически различные разнородные элементы в образах, отражающих программу творчества художника. Образ демона, представленный в серии картин Врубеля, обнажает контекст «болезненных фантазмов» европейского искусства последней трети XIX в.

Продолжением темы катастрофического состояния русского мира на грани двух веков и выявления образно-художественного воплощения оценок современников стала статья Натальи Пращерук (Уральский федеральный университет, Екатеринбург) о творчестве Ивана Бунина. На основании качественного семиотического анализа раскрываются драматические переживания писателя и его проникновение в суть происходящих процессов, касающихся разрушения культурных основ человеческого бытия, приводящих к игре со смертью, к появлению нравственных монстров в душах людей.

Журнал продолжает публикацию материалов конференции «Телесные девиации в русской культуре» (Женевский университет, 23-24 февраля 2018 г.) в повороте к «патологии»- всему тому, что представало и предстает физическими аномалиями на фоне природы и культуры ${ }^{2}$. Этот аспект проявлен в статье Анник Морар (Университет Женевы), посвященной восприятию в конце XIX в. такого явления как гипертрихоз (излишняя волосатость), который становится дифференцирующим признаком, отделяющим собственно людей от образа «иного». Эта игра, в которую включены не только антропология, но и литература, имеет отношение к созданию утопий и антиутопий, использующих данную характеристику человека. Автор справедливо напоминает о практиках показа подобных людей для удовлетворения любопытства толпы в зрелищах, предостерегая тем самым общество от возможных антигуманистических проявлений.

В статье Ярославы Исмуковой (Институт русской литературы РАН, Санкт-Петербург) анализируются «концептуальные монстры» в творчестве Дмитрия Пригова. Сопоставляя примеры поведения мастера во время публичных выступлений и его тексты, автор формирует концептуальное пространство творчества, где монструозность как качество является главнейшей основой конструкции мира поэта.

Блистательный альбом графических работ народного художника РФ Виталия Воловича «Женщины и монстры» оказывается в центре внимания Льва Закса (Гуманитарный университет, Екатеринбург). Исследователь выявляет многообразие художественных ликов монструозности, включающих в себя жизненные проявления эротизма и сексуальности в самых разнообразных коннотациях. Чувства, выраженные в графике художника, колеблются от страха до комизма, от ужаса до любования, доставляя подлинное наслаждение любителям искусства.

2 Редколлегия благодарит организаторов конференции профессора НИУ ВШЭ (СПб.) Константина Богданова и доцента Женевского университета (Швейцария) Анник Морар за конструктивную помощь в формировании этой рубрики в журнале. 
Вторая проблема номера - «Русские и иностранцы в кросскультурном пространстве: идеи и люди» - касается той благой функции культуры, которая позволяет преодолевать разобщение, снимать исторические, языковые, социальные ограничения, расширяя возможности сотрудничества. Способность русского мира к контактам и уверенность в успешности взаимодействия с «иным» в прошлом и в настоящем отечества - не только научная основа для выбора статей, но и объединяющая идея для членов редколлегии, что неоднократно отмечалось в программных статьях к выпускам [Redin, Soboleva]. Эта тема переходит из одного номера в другой и постоянно присутствует в круге наших интересов.

Рубрика выстроена по временной последовательности и открывается статьями, посвященными истории языковых контактов, связанных с взаимодействием церковнославянского и латинского языков. В статье Екатерины Кисловой (Московский государственный университет) на основе архивных источников представлены педагогическая деятельность Феодосия (Яновского) и его труд по созданию новых национально-ориентированных установок изучения церковнославянского языка в первой четверти XVIII в. - «Грамматическое учение». Приведены сведения, уточняющие процесс подготовки учителей, и особенности обучения церковнославянскому языку на грамматической основе. В статье Майи Петровой (Институт всемирной истории РАН, Москва) затрагивается тема движения России к европейскому образованию в связи с обращением к научному языку Средневековья - латыни, объединявшему интеллектуалов Европы. Грамматика Присциана (V-IV в.) и ее европейская (немецкая) переработка стали источником для грамматического сочинения Д. Герасимова («Донат»), становясь предвестником будущего движения просвещенных церковников к выработке системности в изложении морфологии языка.

Совместная статья Александра Строева (Университет Новая Сорбонна, Париж-3, Франция) и Дениса Кондакова (Полоцкий государственный университет, Белоруссия) на основании полицейских отчетов этого времени восстанавливает события первой половины XVIII в., касающиеся особенностей адаптации дипломатов - русского князя и поэта Антиоха Кантемира и датского графа фон Бернсторфа - к высшему парижскому обществу. Им так и не удалось стать полноправной частью французской элиты, сравнение их поведения выявляет принципиально различные приемы завоевания симпатии окружающих в дипломатической деятельности.

Обращение Екатерины II и ее окружения к европейским идеям Просвещения - в центре исследования Людмилы Артамоновой (Самарский государственный институт культуры). Идейная основа взглядов российской аристократии сопрягается с поведенческими практиками 
и убедительно демонстрируют динамику «присвоения» европейских (внешних и внутренних) правил жизни. Эмоционально-чувственный аспект сентиментальных и предромантических представлений нашел воплощение в книжной иллюстрации конца XVIII в. Европейские корни изображаемых образов, по выводам автора статьи Елены Борш, (Уральский государственный архитектурно-художественный университет, Уральский федеральный университет, Екатеринбург), подвергаются существенной коррекции в русских изданиях.

Важной сферой взаимодействия культурных традиций в разные эпохи становились и человеческие взаимоотношения. Мари-Пьер Рец̆, историк французской школы (Университет Париж 1 Пантеон Сорбонна, Франция; Уральский федеральный университет, Екатеринбург), основываясь на мемуарах писателя и дипломата Шатобриана, описывает характер его связей с русским императором Александром І. От внимательного взгляда исследователя на ускользает оценка философом драмы императора, в личности которого противоречиво сочетались политические амбиции и человеческая эмпатия.

Торговля и коммерция, безусловно, являются замечательными примерами межкультурных взаимодействий в истории. В статье Робрехта Деклерка (Гентский университет, Бельгия) представлена амбициозная попытка наладить советско-канадские коммерческие отношения в зоне конфликта. Автор поднимает материалы о неудачной в коммерческом плане, но обогатившей русскую этнографию, географию и историю уникальными сведениями, полученными в результате экспедиции на Камчатку и в Восточную Сибирь, компании «Гудзонов залив» (1919-1925). Достаточно успешное взаимодействие ее участников с местным населением и государственными структурами оказалось недостаточным для успеха из-за невероятных расстояний и сурового климата восточных территорий России.

Рубрика Conceptus et conceptio представлена совместной статьей Игоря Исаева, Аркадия Корнева, Сергея Липеня (Московский государственный юридический университет) о формировании теории властных технологий в современной философии. Авторы видят связь умозаключений с современными тенденциями властных структур и создают систему предостережений, заключающуюся в умении видеть манипулятивные стратегии в политике и законотворчестве представителей власти.

В рубрике Disputatio представлены статьи, насыщенные новыми материалами и идеями. К таковым относится исследование Дениса Ляпина (Елецкий государственный университет), в котором открывается значение социальной организации сельского населения, его роли в общественной, государственной и частной жизни XVII в. И, хотя речь идет об ограниченной территории (Юг России), понятно, что изучение социальной организации сельского населения, состав- 
лявшего подавляющее большинство, дает более конкретные и точные характеристики жизненному устройству той эпохи.

Две последующие статьи обращены к судьбам людей, которые были многочисленными нитями связаны с окружающим миром, как с его предрассудками и сословными условностями, ограниченностью и глупостью, так и с человеческой порядочностью и благородными устремлениями. В статье Владимира Шкерина (Институт истории и археологии УрО РАН, Екатеринбург) напоминается причина ужесточения ссылки украинского поэта Т. Шевченко, отнюдь не красившая поэта (оскорбления в адрес больной императрицы). Социальные столкновения обретали порой неадекватную, неоправданно личностную форму выражения в поведении ссыльного поэта, которому так и не удалось поверить в доброжелательность местной власти в условиях административных ограничений. Интересная в проблемном отношении статья Александра Каменского (Высшая школа экономики, Москва) исходит из желания понять крайние выражения самоотрицания человека - самоубийство в условиях деспотического государства - исходя из концепции «государственного страха». Как показывает автор, это чувство усиливается в периоды тотального контроля, обезличивания власти ввиду бюрократического отношения к судьбе человека без учета обстоятельств и причин его поступков, включая реальный или предполагаемый криминал в государственной сфере.

Бытовые условия детского воспитания, включая развитие моды, становятся в XIX в. объектом внимания создателей одежды. Зарождающееся понимание детского возраста, равноправного взрослению, но имеющего свои особенности, приводит, как показано в статье Натальи Пушкаревой (Институт этнологии и антропологии РАН, Москва) и Натальи Мицюк (Смоленский государственный медицинский университет), к появлению собственно детской моды, вектор которой - освободить ребенка от ограничивающих движение пеленок, сделать одежду удобной и функциональной, соответствующей общественному запросу на новый тип подрастающего поколения. Статья сопровождается визуальными образами (эскизами и фотографиями одежды), ставшими документальным основанием для выводов.

В публикуемых рецензиях (рубрика Controversiae et recensiones) поднимаются вопросы политической истории Московской Руси XVXVI в. В работе Булата Рахимзянова (Институт истории Академии наук Республики Татарстан, Казань) изложены серьезные замечания на претензии А. В. Аксанова изложить историю взаимоотношений Казанского ханства и Московской Руси в герменевтическом ключе. Автор рецензии подробно анализирует логику и аргументацию исследователя, приходя к заключению о доминанте позитивистского подхода в монографии. Дискуссионность рецензии - залог ее ценности 
для читателя журнала. В рецензии Ульяны Головачевой (Уральский федеральный университет, Екатеринбург) рассматривается монография М. М. Крома, посвященная теме рождения Московского государства. Представляется, что ее научно-популярный характер усложняет не только авторскую задачу, но и позицию рецензента, стремящегося понять своеобразие подхода петербургского историка, который пытается разъяснить, соединяя достаточно известные факты и новую информацию, исторический путь России к государственной идее.

\section{Лариса Соболева Уральский федеральный университет, Екатеринбург, Россия}

\section{Список литературы}

Вачева A. Русские и Россия в переписке Валентина Жамре-Дюваля и Анастасии Соколовой (1762-1774) // Quaestio Rossica. T. 6. 2018. № 4. С. 1110-1128. DOI 10.15826/qr.2018.4.349.

Кароли Д. Распространение европейской образовательной модели детских яслей (crèches) в России // Quaestio Rossica. T. 4. 2016. № 3. C. 141-158. DOI 10.15826/ qr.2016.3.180.

Kyденис B. Переводчики XVIII в. и становление историографии как науки в России // Quaestio Rossica. Т. 4. 2016. № 1. С. 235-260. DOI 10.15826/qr.2016.1.152.

Приказчикова Е. «Духовный рыцарь» И. Лопухин: диалог с властью и совестью // Quaestio Rossica. T. 6. 2018. № 3. C. 711-726. DOI 10.15826/qr.2018.3.323.

Смирнов И. Вечное вырождение // Неприкосновенный запас. 2018. № 1. С. 11-29.

Христофоров В. Американские дипломаты на rendez-vous с советской политикой и русской культурой (1941-1945) // Quaestio Rossica. T. 4. 2016. № 2. С. 119-136. DOI 10.15826/qr.2016.2.162.

Binney M. Empire, Spectacle and the Patriot King : British Responses to EighteenthCentury Russian Empire // Quaestio Rossica. T. 5. 2017. № 2. C. 385-405. DOI 10.15826/ qr.2017.2.232.

Quaestio Rossica. T. 7. 2019. № 1. C. 140-240.

Redin D., Soboleva L. The Epoch of the Enlightenment : From the Voyages of Peter I to the Ideas of the Catherinian Period // Quaestio Rossica. T. 5. 2017. № 2. P. 303-312. DOI 10.15826/qr.2017.2.224.

Zhuk S. 1968: One Year in the Life of a Soviet Americanist, or American Influence at Home and Abroad during the Cold War // Quaestio Rossica. T. 4. 2016. № 2. C. 15-42. DOI 10.15826/qr.2016.2.157.

\section{References}

Binney, M. (2017). Empire, Spectacle and the Patriot King: British Responses to Eighteenth-Century Russian Empire. In Quaestio Rossica. Vol. 5. No. 2, pp. 385-405. DOI 10.15826/qr.2017.2.232.

Caroli, D. (2016). Rasprostranenie evropeiskoi obrazovatel'noi modeli detskikh yaslei (crèches) v Rossii [The Introduction and Spread of European-Style Crèches in Russia]. In Quaestio Rossica. Vol. 4. No. 3, pp. 141-158. DOI 10.15826/qr.2016.3.180.

Coudenys, W. (2016). Perevodchiki XVIII v. i stanovlenie istoriografii kak nauki v Rossii [Translators and the Emergence of Historiography in Eighteenth-Century Russia]. In Quaestio Rossica. Vol. 4. No. 1, pp. 235-260. DOI 10.15826/qr.2016.1.152. 
Khristoforov, V. (2016). Amerikanskie diplomaty na rendez-vous s sovetskoi politikoi i russkoi kul'turoi (1941-1945) [American Diplomats on a Rendezvous with Soviet Policy and Russian Culture (1941-1945)]. In Quaestio Rossica. Vol. 4. No. 2, pp. 119-136. DOI 10.15826/qr.2016.2.162.

Prikazchikova, E. (2018). “Dukhovnyi rytsar'” I. Lopukhin: dialog s vlast'yu i sovest'yu [I. Lopukhin, a "Spiritual Knight": A Dialogue with Power and Conscience]. In Quaestio Rossica. Vol. 6. No. 3, pp. 711-726. DOI 10.15826/qr.2018.3.323.

Quaestio Rossica. (2019). Vol. 7. No. 1, pp. 140-240.

Redin, D., Soboleva, L. (2017). The Epoch of the Enlightenment: From the Voyages of Peter I to the Ideas of the Catherinian Period. In Quaestio Rossica. Vol. 5. No. 2, pp. 303-312. DOI 10.15826/qr.2017.2.224.

Smirnov, I. (2018). Vechnoe vyrozhdenie [Eternal Degeneration]. In Neprikosnovennyi zapas. No. 1, pp. 11-29.

Vacheva, A. (2018). Russkie i Rossiya v perepiske Valentina Zhamre-Dyuvalya i Anastasii Sokolovoi (1762-1774) [The Russians and Russia in the Correspondence between Valentin Jamerai-Duval and Anastasia Sokolova (1762-1774)]. In Quaestio Rossica. Vol. 6. No. 4, pp. 1110-1128. DOI 10.15826/qr.2018.4.349.

Zhuk, S. (2016). 1968: One Year in the Life of a Soviet Americanist, or American Influence at Home and Abroad during the Cold War. In Quaestio Rossica. Vol. 4. No. 2, pp. 15-42. DOI 10.15826/qr.2016.2.157. 